\title{
A Call to Action: Reimagining Social Work Practice With Unaccompanied Minors
}

\author{
Kerri Evans \\ Kylie Diebold \\ Rocío Calvo
}

\begin{abstract}
In the decade leading up to 2012, approximately 8,000 Unaccompanied Minors (UAM) arrived annually at the Southwestern border of the United States. Since then, the number of arrivals has drastically increased, surpassing 14,000 between October 1, 2017 and January 31, 2018 alone. The needs of UAM concerning mental health, education, social, and legal counseling often differ from the needs of other Latinx and immigrant populations. However, recent instability in the protections and services tailored to UAM are channeling these youth and their families into mainstream agencies. This article is a call to action for social workers who may now encounter UAM for the first time in their practice. Drawing from almost twelve years of practice experience working with UAM and their families, as family case managers, community liaisons, program managers, grant administrators, and training facilitators, we review needs, services, and promising practices for social work practice with UAM. Recommendations include providing education to parents and caregivers about UAM's rights, U.S. laws and regulations, and service availability; building trust and rapport with families; creating welcoming schools; practicing cultural openness; hiring diverse staff; and fostering partnerships with local service providers.
\end{abstract}

Keywords: Migrant; unaccompanied minor; unaccompanied child; promising practices; Central America; northern triangle, family reunification

Unaccompanied minors (UAM) (also known as Unaccompanied Children (UC) and Unaccompanied Alien Children (UAC)) are a growing population in the United States (U.S.). Although they hold membership in both the Latinx and the undocumented communities, UAM come to the U.S. with a specific history that sets them apart from other Latinx and undocumented persons. Their pre-migration circumstances, migration journey, integration into life in the U.S., and legal status, lead unaccompanied children to struggle with acculturative stress, social isolation, discrimination, and criminalization (De Genova \& Peutz, 2010; Perreira \& Ornelas, 2011). These circumstances make youth vulnerable to depression, anxiety, low self-esteem, irritability, aggression, and post-traumatic stress disorder (Carlson, Cacciatore, \& Klimek, 2012; Perreira \& Ornelas, 2011).

The presence of UAM in the U.S. is increasing, but funding for services specifically tailored for this population fluctuates significantly annually. For instance, the President's Fiscal Year (FY) 2019 Budget requests \$1,148 million for the UAM program, an increase of \$206 million above the FY18 Continuing Resolution, but \$267 million below the FY17

\footnotetext{
Kerri Evans, MSW, LCSW is a doctoral student at Boston College, Chestnut Hill MA02467. Kylie Diebold, MSW is a Children's Services Specialist for Foster Care at the United States Conference of Catholic Bishops,

Migration and Refugee Services. Rocío Calvo, PhD is an Associate Professor at Boston College School of Social Work.

The opinions expressed herein are those of the author alone and do not necessarily represent the opinions or positions of the United States Conference of Catholic Bishops 
budget (Department of Health and Human Services [HHS], 2018). The FY19 funding request for similar programs and services for refugees was decreased to $\$ 515$ million, approximately 25\% lower than the FY18 Continuing Resolution (HHS, 2018). Given funding uncertainties and proposed rollbacks to UAM protections and services, UAM youth and their families are being channeled into mainstream services. Consequently, social workers should be prepared to work with this population regardless of their role or specialty.

The article proceeds as follows, first we provide a brief overview of UAM including who they are, where they come from, and the federal programs tailored to address UAM needs post-arrival. Then, we discuss how these services meet the needs of UAM, as well as the gaps in service, followed by a review of UAM outcomes. We conclude with a call to reimagine social work with UAM where we provide recommendations and promising practices for social workers in a variety of settings, such as community health care centers, schools, and the child welfare system; and about a number of topics such as the importance of education regarding U.S. laws, culturally and linguistically appropriate service delivery, and strengthening community partnerships.

\section{Unaccompanied Minors: Who Are They, Where Do They Come From, and What Happens after Their Arrival in the U.S.?}

The Homeland Security Act of 2002 Public Law 107-296, 6 U.S.C. § defines UAM as individuals under the age of eighteen who arrive at the U.S. border without lawful immigration status or a parent or legal guardian to provide care and physical custody. Most of these children come to the U.S. from the Central American countries of El Salvador, Guatemala, and Honduras, collectively known as the Northern Triangle (Administration for Children and Families [ACF], 2017a). Many UAM are apprehended by the Department of Homeland Security upon arrival at the U.S. border. Children from the contiguous countries of Mexico and Canada who do not demonstrate signs of trafficking or fear of persecution (about six percent annually) are repatriated back to their country of origin, as required under the William Wilberforce Trafficking Victims Protection Reauthorization Act (TVPRA) of 2008 Public Law 110-457 (Ramirez, McKenna, \& Somers, 2015; United States Conference of Catholic Bishops [USCCB], 2012). The remaining 94 percent are placed under the care and custody of the U.S. Department of Health and Human Services, Office of Refugee Resettlement (ORR), and are subject to removal.

In the decade leading up to 2012, the average number of UAM arriving at the U.S. border annually ranged from 7,000 to 8,000 (ACF, 2016). Escalating persecution, economic hardship, and violence in the Northern Triangle caused the number to increase drastically between 2012 and 2016 (Customs and Border Protection [CBP], 2016; ACF, 2017b). While the number of arrivals tapered off in FY2017, there has been a steady increase since the start of FY2018, with 14,444 UAM arriving between October 1, 2017 and January 31, 2018 (CBP, 2018). See Table 1 for a breakdown of UAM arrival statistics between FY2012 and FY2017, as complete 2018 data is not yet available. 
Table 1. UAM Arrival Information FY2012-FY2017

\begin{tabular}{|c|c|c|c|c|c|}
\hline \multirow[b]{2}{*}{ Fiscal Year } & \multirow{2}{*}{$\begin{array}{c}\text { SW Border } \\
\text { Apprehensions }\end{array}$} & \multicolumn{2}{|c|}{ Gender* } & \multicolumn{2}{|c|}{ Age* $^{*}$} \\
\hline & & Male & Female & $0-14 y$ & $15-17 y$ \\
\hline FY2012 & $24,403^{\mathrm{a}}$ & $77 \%$ & $23 \%$ & $22 \%$ & $77 \%$ \\
\hline FY2013 & $38,759^{a}$ & $73 \%$ & $27 \%$ & $27 \%$ & $74 \%$ \\
\hline FY2014 & $68,541^{\mathrm{a}}$ & $66 \%$ & $34 \%$ & $37 \%$ & $63 \%$ \\
\hline FY2015 & $39,970^{a}$ & $68 \%$ & $32 \%$ & $31 \%$ & $68 \%$ \\
\hline FY2016 & $59,692^{b}$ & $67 \%$ & $33 \%$ & $32 \%$ & $68 \%$ \\
\hline FY2017 & $41,435^{b}$ & $68 \%$ & $32 \%$ & $30 \%$ & $69 \%$ \\
\hline
\end{tabular}

While reasons for fleeing are complex and unique for each child, most youth seek protection from various forms of persecution, abuse, deteriorating social and economic conditions, as well as gang and generalized violence in their home countries (Crea, Hasson, Evans, Berger Cardoso, \& Underwood, 2017a; Piwowarczyk, 2006; United Nations High Commissioner for Refugees [UNHCR], 2014). The long and dangerous journey to the U.S. adds to the risk of traumatic outcomes for UAM (Pine \& Drachman, 2005). Many UAM are victims or witnesses to sexual or physical violence, go without food or water for days at a time, walk and take trains under harsh conditions, and are forced to negotiate with smugglers (Griffin, Son, \& Shapleigh, 2014; UNHCR, 2014). Upon arrival in the U.S., UAM require specialized interventions and services to overcome their trauma and work towards positive life outcomes.

Legal status and legal relief. The U.S. government is not mandated to appoint attorneys to UAM who are in removal proceedings. Due to financial and time constraints, only about half of the UAM who face deportation secure legal representation (Kids in Need of Defense [KIND], 2016). When navigating the complex U.S. immigration system, UAM who have an attorney are much more likely to be granted some form of protection than children without representation (KIND, 2016). Seventy-eight percent of UAM who attend their scheduled hearings receive some form of relief and remain in the U.S. undocumented (Migration Policy Institute [MPI], 2015). The most common form is administrative case closure, a status that means the child is no longer in active removal proceedings (MPI, 2015). Less than five percent of UAM are granted legal status through one of the following forms of immigration relief for which they may be eligible: Asylum, Special Immigrant Juvenile Status (SIJS), U Nonimmigrant Visas, and T Nonimmigrant Visas (MPI, 2015).

\section{Federally Mandated Services for UAM}

The ORR provides shelter care, post-release services (PRS), and foster care to UAM who are apprehended at the southern border. These federally funded services are mandated by the Flores Settlement Agreement of 1997 Case No. CV 85-4544-RJK (C.D. CA, 1997), the Homeland Security Act of 2002, and the Trafficking Victims Protection Reauthorization Act of 2008 (USCCB, 2012). 
Shelter care. Upon arrival to the U.S., apprehended youth are transferred to the custody of the ORR and placed into shelters that are funded by the ORR and operated by child welfare agencies licensed by the state in which they are located. These shelters provide children with access to education, health care, mental health services, legal screenings, and case management, as well as assistance with family finding and reunification services (ACF, 2017a). Most UAM stay in shelter care for an average of 34 days (ACF, 2017b), after which, around 90 percent of children are reunified with an adult relative or caregiver in the U.S., referred to as a sponsor (ACF, 2017c). Approximately one percent of UAM meet eligibility for the Long-Term Foster Care (LTFC) program. The remaining UAM, around ten percent, are returned to their home country through voluntary departure or removal (USCCB, 2012).

Post-Release Services (PRS). Approximately 20 percent of children who are reunified with a sponsor receive PRS to help with the transition into their new home and community (ACF, 2017b). These services, which include case management and linkages to education, health care including mental health, and legal representation, are coordinated by social workers who help address the unique needs of reunified UAM (Roth \& Grace, 2015). UAM qualify for PRS according to their assessment of needs, their relationship to the sponsor, and the motivation and ability of the sponsor to adequately care for the child (USCCB \& Lutheran Immigration and Refugee Service, n.d.). Services generally last for 90 days, but on some occasions are provided for the duration of the child's removal proceedings, or until the child turns eighteen years old.

Foster Care. The Long-Term Foster Care (LTFC) program consists of a network of local agencies that provide culturally sensitive foster care and group home services to less than three percent\% of UAM, those who do not have a qualified and appropriate sponsor to care for them and who have been identified as eligible for immigration relief (ACF, 2015a). In most instances, UAM who qualify for LTFC were abused, abandoned, or neglected by one or both parents in their home country, have an asylum claim, or are victims of human trafficking (USCCB, 2012).

To aid in the integration process, the agency providing care must ensure that UAM are placed in a licensed foster home or group home, enrolled in school, and have access to medical care, counseling, recreation, and legal representation (ACF, 2015a). Children are eligible to remain in LTFC until a viable reunification option becomes available, they turn eighteen, or until they are granted legal relief and transition into the Unaccompanied Refugee Minor (URM) program. The URM foster care program is uniquely tailored for foreign-born youth and is subject to the child welfare laws and guidelines in the state in which it is located. As such, it is designed to help unaccompanied migrant and refugee children develop the skills to become self-sufficient and successfully transition into adulthood (ACF, 2015b).

\section{Do Services Meet the Needs of UAM?}

Services rendered by the PRS and LTFC programs are mandated by federal legislation (Flores Settlement Agreement, Homeland Security Act, and TVPRA), but are contingent upon funding availability, and the current situation leaves thousands of UAM underserved 
every year. Historically, eligible UAM and their families were offered assistance through the PRS program for at least six months. However, for most UAM and their families, this period of assistance was reduced to three months during 2016. The shorted eligibility time frame has led to many unresolved needs at the end of services, and to increased risks for UAM for poor educational outcomes, ongoing mental health concerns, and immigration issues (Roth \& Grace, 2015).

A concern with the LTFC program is that there are not enough funded slots for the youth who meet the eligibility criteria. Additionally, as with domestic foster care, there are not enough families willing to take and be trained to serve culturally diverse youth (DiNitto, 2011). For UAM this is compounded by people's preconceived notions of helping an undocumented child, hate, fear, and the perceived challenges of housing a child who speaks a different language (American Federation of Teachers, n.d.). Eligible UAM who are unable to access the LTFC program remain in shelters long-term, which violates the child welfare best practice of placing children in the least restrictive setting.

The lack of services tailored to meet the needs of UAM has channeled these youth and their families into social welfare programs and community-based services. Roth and Grace (2015) note that UAM encounter many service providers and that social workers in schools, hospitals, legal clinics, and elsewhere "need to develop a broader recognition of the unique challenges that varying immigration statuses pose for children and their families” (p. 251). For mixed immigration status families with children born in the U.S., the natural citizens may be eligible for programs such as Medicare, Supplemental Nutrition Assistance Program, and Temporary Assistance for Needy Families (Haider, Schoeni, Bao, \& Danielson, 2004). However, the Personal Responsibility and Work Opportunity Reconciliation Act of 1996 bars undocumented immigrants from receiving federal welfare benefits, and even UAM who obtain legal relief must wait five years before they are eligible to apply for benefits (Haider et al., 2004). As a result, many UAM and their families rely on the support of family and local nonprofit services not aimed at the UAM population.

\section{UAM in the U.S.}

Literature suggests that negative experiences of children prior to migration influence their behavior after arrival (Crea, Lopez, Taylor, \& Underwood, 2017b). However, there is little systematic research that specifically discusses the needs, or the long-term outcomes of UAM who do not receive services tailored to their needs. This lack of information is compounded by a lack of indicators and instruments for caseworkers to both assess mental health concerns and make appropriate referrals (Cardoso et al., in press; Crea et al., 2017b). The discussion below summarizes the limited research on these topics.

\section{Health and Mental Health}

Children who have experienced forced migration are particularly vulnerable to mental health concerns (Kennedy, 2013; Piwowarczyk, 2006). Most UAM enter the U.S. with preflight trauma, and fewer than 20 percent had access to health care in their home country (Kennedy, 2013). A study of pre-flight trauma among UAM showed that almost half of participants were displaced by drug cartel or gang related violence, or by government 
actors. Almost a quarter of UAM were victims of abuse and violence within their family, and ten percent of participants were exploited by smugglers (UNHCR, 2014).

Untreated historical trauma, combined with the trauma suffered during migration and the difficult adjustment post-arrival, places UAM at risk for undesired mental health outcomes if the trauma is unaddressed (Kennedy, 2013; Pine \& Drachman, 2005). Accessibility of treatment is a significant challenge for this population due to language barriers, lack of transportation, lack of health insurance, cost, and cultural norms around seeking professional mental health services (Hacker, Anies, Folb, \& Zallman, 2015). Utilization of medical services such as blood transfusion, organ transplant, and immunizations also vary for people of some religious and cultural backgrounds (Blood Weekly, 2016; Grabenstein, 2013). Finding culturally competent organizations that offer no-cost and low-cost health services for uninsured, undocumented immigrants can be problematic; long wait times, complex paperwork, and fear of discrimination and deportation often reinforce the barriers that prevent access (Hacker et al., 2015; Redden, 2017; Roth \& Grace, 2015).

\section{Education}

Equal access to opportunities for advancement is key for the integration of immigrants. Education is at the forefront of such opportunities (Calvo, Teasley, Goldbach, McRoy, \& Padilla, 2018; Waters \& Pineau, 2015). All children in the U.S. have a right to attend public schools regardless of country of birth (U.S. Department of Education [U.S. DOE], 2014). However, UAM are often denied enrollment, diverted to alternative schools, or face delays in the enrollment process when they lack the required documentation (i.e., birth certificate, proof of residence, immunization records, and transcripts (Booi et al., 2016; Bridging Refugee Youth and Children's Services, 2016). Unfortunately, the circumstances which force most UAM to leave their countries also prevent these youth from obtaining important documentation and personal records prior to migration (UNHCR, 2016).

These experiences with the school system heighten the risk of experiencing discrimination and social isolation, which in turn may influence academic outcomes (Oxman-Martinez \& Choi, 2014). Additionally, immigrant children with little or no formal education have unique academic needs for which schools and educators across the country are sometimes unprepared (Booi et al., 2016). These factors widen the achievement gap between UAM and their English-speaking peers (López \& Radford, 2017). Permanent legal status has been found to increase graduation rates for UAM in high school (Crea et al., 2017a; Kohli, 2011).

\section{Child Welfare}

The ORR has a federal foster care program that serves a small percentage of UAM annually, but UAM and their families may also interact with the state-based child welfare system through investigations, family preservation services, foster care, or adoption. For youth who are released from the ORR care into the community, the prolonged family separation (Roth \& Grace, 2015), adultification (Trickett, Jones, \& Nagayama, 2007), and

adjustment to a new community, can result in family breakdown and involvement with the 
child welfare system. Additionally, many UAM enter the child welfare system when their parents are either detained or deported (Applied Research Center, 2011).

Cultural norms of immigrant families may alter social worker's ability to accurately identify problems or conflict (Patil, Mcgown, Nahayo, \& Hadley, 2010). Relatedly, permanency and family finding can be slightly different for UAM in the foster care system because their family may not speak English, may not have legal status in the U.S., or may not reside in the U.S. (Socha, 2014). As with any other child in the foster care system, when reunification is not possible, adoption may be considered as an option for UC even if they entered the country without authorization as legal immigration status is not required to be eligible for adoption in the U.S. (Department of State, 2017). However, the largest challenge in pursuing adoption for UAM is that they often have a biological parent in home country with whom they maintain contact so termination of parental rights may not be feasible, and/or in the child's best interest. Proving the death of a parent can also be a challenge in countries where formal death certificates are not kept, the cost of paperwork is prohibitive, or if the death happened in transit when fleeing the home country (International Human Rights Clinic, 2015).

\section{U.S. Laws and Regulations}

Laws are stringent and better enforced in the U.S. than in some Central American countries (USCCB, 2013a), and violation of any U.S. law by an undocumented person can have harsh implications, including deportation (Catholic Legal Immigration Network, 2016). It is not uncommon for immigrant families to be unfamiliar with U.S. laws, especially among recent arrivals. Important laws that can be a source of concern include activities such as driving without a license; alcohol consumption under the age of 21; purchasing tobacco products under the age of eighteen; and illicit drug use (USCCB, 2013a). In addition, using physical harm to discipline a child and using physical aggression towards a spouse or partner is prohibited in the U.S., and school attendance is mandatory in most states for children between the ages six to sixteen (USCCB, 2013a).

\section{A Call for Action}

UAM are now more likely than ever to interact with mainstream social services. The authors of this manuscript draw from their direct practice experience with UAM, as well as from their experience administering programs that serve UAM, to prepare all social workers for work with this population. At the direct practice level, the authors have experience in case management for the PRS program where support was given to families to ensure their connection to local community services at the time of reunification. Additional direct practice experience included partnership-building with community organizations and schools to increase awareness and service availability for UAM. At the macro level, the authors' experience has been gained via employment for the ORRcontracted agencies that provide oversight for federally mandated UAM programs across the U.S. In this role, the authors engaged in program development, program management, training facilitation for direct care staff, and quality assurance of case management, and foster care services specifically for UAM youth. A thorough understanding of UAM programming requirements, child welfare best practices, and the unique needs of UAM 
was acquired over almost 12 years of combined social work practice with UAM. Given the current shift in funding and priorities for UAM, the authors worked together to reflect upon their experiences and draw out the most salient themes as advice for other social workers.

\section{Recommendations for Social Workers}

Based on the gaps identified above, and on many years of social work practice experience with UAM held by the authors, the following sections outline promising practices to improve social work practice with UAM for mainstream service providers. We focus on: (1) access to health and mental health services, (2) navigating the educational system, (3) involvement with the child welfare system, (4) understanding U.S. laws and regulations, (5) ensuring culturally relevant service delivery, and (6) building community partnerships.

\section{Health and Mental Health Services}

When working with undocumented families without healthcare coverage, we recommend utilizing no-cost and low-cost health services whenever they do not require proof of residency (Ciaccia \& John, 2016). In communities where low-cost mental health options are scarce, we suggest utilizing alternative services such as mentoring programs and church support groups and activities as these were found to be successful for unaccompanied minors from Eritrea (Socha, Mullooly, \& Jackson, 2016). In emergency situations, hospital services are always available to families without insurance. However, we recommend that social work agencies build partnerships with local medical providers so they may be more willing to serve populations outside of their typical clientele. Social workers may also be instrumental in advocating for healthcare expansion within their own communities and at the national level by making a case for benefits to be extended to undocumented individuals.

\section{The Educational System}

We recommend that social workers advocate for the enrollment of UAM to ensure that all youth are given the opportunity to learn and grow. This can be done through the flexibility of the McKinney-Vento Act of 2001 to overcome residency requirements (U.S. DOE, 2004), and use of the ORR's case documents for evidence of immunizations, age, and to explain the absence of a legal guardian in the U.S. (Evans, Perez-Aponte, McRoy, in press). Case documents can be also used to inform the system about the educational systems in the countries of origin, and thus, to overcome transcript requirements. Social workers also play a vital role in ensuring that UAM are properly assessed upon entering school and are provided with the appropriate English Language Learner (ELL) supports as required under the Equal Educational Opportunities Act of 1974, and Every Student Succeeds Act of 2015 (U.S. DOE, 2016; Equal Educational Opportunities Act of 1974) when parents/caregivers are unfamiliar with local resources. Booi et al. (2016) discussed the nuances of disability testing and Individual Education Plans (IEP) for undocumented youth. 
After enrollment, social workers should provide, or work with community organizations to provide teachers and administrators with training on the background of UAM, cultural norms in Central American countries, and the impact of childhood trauma (Morland, Duncan, Hoebing, Kirschke, \& Schmidt, 2005; Evans, Perez-Aponte, \&McRoy, in press). When schools adopt a welcoming environment and staff understand the ways in which UAM are similar to and different from other refugee and immigrant children, they may be better equipped to meet their needs (Barillas, 2010). School personnel should engage parents and caregivers of UAM early to build trust and create a culture of support in integrating immigrant children because school is often the first place that UAM interact with community members outside of their ethnic or cultural group. Encouraging the use of the co-teaching model in schools with high numbers of UAM and other ELLs enables one teacher to "determine the learning target, pacing of content, and alignment to standards" while the other facilitates learning, enabling non-English speakers to better learn (Beninghof \& Leensvaart, 2016). Lastly, social workers must play a role in the detection and consequences of discriminatory behaviors in the school setting and in the community at large.

\section{The Child Welfare System}

When social workers encounter UAM and their families in the child welfare system, we recommend that they be responsive to sociocultural background (Pottie et al., 2011), and avoid stereotyping, especially during child welfare investigations. Dettlaff and Rycraft (2010) describe best practices for working with Latino families in the child welfare system that honors the cultural values and differences. We recommend that workers be cognizant of cultural differences and family constraints; making assumptions can be dangerous. Whenever possible, researching the culture of the family before a home visit can enable the caseworker to be more confident and allow for a deeper conversation with the family regarding how behaviors or norms are different in the U.S. versus in the family's home country. Morland et al. (2005) also recommend working alongside ethnic leaders and cultural brokers to gain trust. For example, methods of discipline vary widely around the world and caregivers may lack skills for behavior modification, as deemed appropriate in the U.S., without assistance. It is also not uncommon for immigrant families to live in what may appear to be crowded, multi-generational households (Booi et al., 2016; Halpern, 2008). Lack of space should always be carefully weighed with the benefits of living with family prior to removing a child from a home. We recommend using an ecological systems theory to help the family expand their network, mobilize support and increase coping skills (Paat, 2013). This can also be done through actions such as providing referrals for all family members to services such as English classes, community activities, family mentoring, internet safety courses, and mock court sessions.

For UAM who enter foster care, social workers should persist in attempting to locate family members to provide care for them. Social workers should ask for extensions in the standard family finding process and repeat the search process every couple of months, being creative in their approach each time. Family tracing should be ongoing because UAM may have new family members who arrive to the U.S. over time. Similarly, using the cultural definition of "family" can extend the potential caregiver pool to include fictive kin, 
neighbors, godparents, and the like (Socha, 2014). When searching for family in other countries and assessing them as potential caregivers, conducting online searches, (i.e., through social media platforms), or using the services of agencies such as The International Committee of the Red Cross (ICRC) Restoring Family Links Program or International Social Service's family tracing services can be invaluable (ICRC, n.d.; International Social Service, 2017). Language barriers, poor conditions in home country, and legal status are not appropriate reasons to overlook family in the search or assessment process. When considering adoption for a UAM youth, we recommend carefully weighing all the options and ensuring that family reunification options both in the U.S. and abroad have thoroughly been explored. If UAM are being considered for adoption in the U.S. or to return to family in home country, social workers should encourage appointment of a child advocate to conduct a best interest determination (BID) which can help to examine the advantages and disadvantages to living in each country (Evenhuis, 2013).

\section{U.S. Laws and Regulations}

We recommend that social workers provide education to UAM and their families regarding ways that American laws and customs differ from those in their home country. In many communities, social workers can refer clients to existing classes that provide this information to new community members. In other cases, they can create classes and resources, or provide ad hoc education. The Refugee Cultural Orientation program is a resource that could be used as a model in developing a training plan (Cultural Orientation Resource Center, 2018). Always keep in mind that it is better to be proactive in providing information on U.S. laws rather than reactive.

\section{Culturally Relevant Service Delivery}

To ensure effective service delivery for UAM, mainstream service providers and social workers should obtain training about the specific needs of this population, so services can be adapted. More specifically we saw that service providers enjoyed training specific to this population (USCCB, 2013b) and therefore recommend training on trauma-informed care, cultural competency, and human trafficking for staff that interact with UAM (Morland et al., 2005).

Additionally, we recommend that agencies hire culturally diverse staff who can relate to UAM to ease the adjustment process. This could include Latinxs, Spanish speakers, adults who came to the U.S. as a UAM, people who have lived and worked abroad, or family members of UAM. We often found that service delivery is most effective when culturally-relatable paraprofessional staff work alongside trained social workers to provide complementary aspects of holistic care (Linsk, 2014), so that the UAM have different people from whom they can seek guidance.

Client satisfaction surveys can be an excellent way to assess the perspectives of UAM and their caregivers on their experience with the agency. It is important to note that these surveys should be made available in multiple languages, and administered verbally rather than in written form when necessary to better gauge each UAM's experience and feedback. 


\section{Community Partnerships}

Both managers and frontline staff play an important role in the development of formal and informal community partnerships. These relationships are crucial to ensure access to services for UAM clients. A social worker's ability to facilitate referrals to services for UAM improves when there are pre-existing relationships between the social worker, their agency of employment, and external organizations. We recommend building and maintaining partnerships with community organizations such as legal providers, mental health clinics, health clinics, food banks, schools, and adult learning programs. Additionally, churches can provide a wealth of assistance including financial support, volunteers, temporary housing assistance, child care, clothing, and food. Morland et al. (2005) recommend partnerships with refugee service agencies and hosting "cross-service training" events that facilitate interagency communication, resource sharing, and coordination between local agencies.

When a gap in resources or services is identified, seeking new opportunities for collaboration can ensure the need is met. This might mean reaching out to an existing organization to extend services to UAM. In exchange for increased referrals, request that staff at the partnering organization partake in UAM-related training and offer assistance with interpretation services for the child during appointments. These can be very fruitful partnerships as they create opportunities to develop new programming crafted to the specific needs of UAM. For example, an agency that provides legal services to UAM released from federal custody recently started to contract social workers after realizing that their UAM clients need more than just legal help. This partnership has enabled UAM and their families to connect with local services and resources in the community. While many UAM encounter legal service providers, very few receive post-release services, so having a social worker on staff makes a significant impact.

\section{General Recommendations}

In addition to specific recommendations linked to particular social work areas above, there are other recommendations that span all practice settings. For instance, all social workers should build trust and rapport with UAM and their families so that they feel comfortable asking for help and referrals to the services they need (Roth \& Grace, 2015). Establishing a relationship requires that social workers are familiar with their client's culture (Aggarwal et al., 2016), respect their right to self-determination (NASW, 1996), and work with the client to resolve issues. Additionally, social workers can educate families on their rights, dispel myths, and assist families in finding safe ways to engage with the community they live in.

Social workers and case managers should also help UAM and their families to increase their knowledge of local resources and where to seek help in the community. Social workers should first connect UAM and their families to agencies that focus on services for Latinxs, as these service providers will be best equipped to meet their cultural and linguistic needs. However, practitioners should not hesitate to refer families to mainstream services when a need cannot otherwise be met. When using mainstream providers, social workers should advocate that the agency (such as doctor's offices, courts, and schools)provide 
interpretation for families who may need it. However, it is important to ask the family about their preferred language first because while Spanish is the first language of many UAM, some arrive with little or no familiarity with Spanish and instead speak an indigenous dialect such as K’iche' or Mam (Crea et al., 2017a). Refer to the Civil Rights Act of 1964, the Affordable Care Act of 2010, and the Court Interpreters Act, 28 U.S.C. §1827 to make providers aware of their obligation to provide interpretation (Administrative Office of the U.S. Courts, n.d.; CME Learning, 2017). If this is unsuccessful, social workers can connect UAM to pro-bono language services such as college interns studying languages, community volunteers, telephonic interpretation, or web-based applications as needed. It is important to ensure that these individuals have received the required training to comply with the confidentiality regulations of interpreters.

\section{Discussion}

Grounded in years of experience working with UAM across a variety of settings, this manuscript reimagines social work practice with these youth, highlights lessons learned, and proposes promising practices for social workers who may encounter UAM in their daily practice. Because UAM are a relatively recent population, professional social workers who have been practicing for a while may not have learned about UAM during their social work education. With the appropriate training, we can adapt mainstream service delivery to guarantee that the needs of UAM are successfully addressed.

It takes a community to provide UAM with the full range of services that they may require. Our recommendation to build community partnerships with other agencies is consistent with other areas of social work practice. For example, Alter (2009) found that the sustainability of human service organizations today is highly dependent on the extent of their partnerships within the local community. Moreover, few organizations that attempt to operate completely independently can function long-term. Collaboration plays a critical role in strengthening the services available, meeting previously unmet needs, and achieving positive long-term outcomes (Alter, 2009; Shore, Hammond, \& Celep, 2013). Establishing relationships with places of worship for various religions is also highly recommended, as connecting unaccompanied minors with the appropriate faith-based institution can help them cope with their new surroundings and prevent feelings of isolation (Raghallaigh, 2011).

Ensuring effective service delivery falls to supervisors, program managers, and macro social workers in most agencies. Hiring both bilingual/bicultural paraprofessional staff (Roth \& Grace, 2015; Linsk, 2014) as well as trained social workers plays an important role in service delivery. Similarly, Earner (2005) recommends that specialists in child welfare and refugee and immigrant serving agencies be cross-trained to ensure that they are aware of the nuances of serving this population (Morland et al., 2005); the advice for cross-training can span beyond child welfare. When thinking about adapting services to UAM we also need to be cognizant of the differences among UAM themselves. For example, a study found that UAM from Guatemala were eight times more likely to only achieve a K-12 education by time they discharged from foster care than youth from other 
countries (Crea et al., 2017a), suggesting that cultural and linguistic differences have an impact on UAM educational attainment.

Considering what we know about UAM education, the ideas of prompt enrollment in local schools and welcoming school environments is key to their educational success. Research shows that racism, xenophobia, acculturative stress, and behaviors of cultural discrimination can hinder immigrant students' ability to succeed in the classroom (KumiYeboah \& Smith, 2017). However, when placed in positive school environments with supportive teachers, these students show incredible resiliency to succeed (Kumi-Yeboah \& Smith, 2017). Furthermore, a study found that UAM and other ELLs experience increased educational outcomes when they are integrated into classrooms with native Englishspeaking students, rather than isolated into classrooms for newcomers for an extended period of time (Beninghof \& Leensvaart, 2016; Pardini, 2006).

\section{Conclusion}

The number of Central American UAM in the U.S. has increased considerably since the early 2000s. These children flee their home countries for various reasons, including community violence, persecution, and economic hardship. Their home situation and journey to the U.S. often includes traumatic experiences such as abuse, abandonment, violence, and involvement with smugglers. Some services such as shelter care, post-release services, and long-term foster care are mandated by federal legislation and are designed to help UAM when they arrive to the U.S. However, these services are limited in funding and scope, and therefore mainstream service providers need the knowledge and tools to appropriately adapt their services to meet the needs of UAM. All social workers have a vital role to play in helping UAM to process, overcome, and thrive in their new communities.

\section{References}

Administration for Children and Families [ACF]. (2015a). Children entering the United

States unaccompanied. Retrieved from https://www.acf.hhs.gov/orr/resource/children-entering-the-united-statesunaccompanied.

ACF. (2015b). About unaccompanied refugee minors. Retrieved from https://www.acf.hhs.gov/orr/programs/urm/about

ACF. (2016). Fact sheet. Retrieved from https://www.acf.hhs.gov/sites/default/files/orr/orr_fact_sheet_on_unaccompanied_ali en_childrens_services_0.pdf

ACF. (2017a). About unaccompanied alien children's services. Retrieved from https://www.acf.hhs.gov/orr/programs/ucs/about

ACF. (2017b). Facts and data. Retrieved from https://www.acf.hhs.gov/orr/about/ucs/facts-and-data 
ACF. (2017c). Unaccompanied alien children released to sponsors by state. Retrieved https://www.acf.hhs.gov/orr/resource/unaccompanied-alien-children-released-tosponsors-by-state.

Administrative Office of the U.S. Courts. (n.d.). Federal court interpreters. Retrieved from http://www.uscourts.gov/services-forms/federal-court-interpreters

Aggarwal, N. K., Farias, P. J., Becker, A. E., Like, R., Lu, F., Oryema, N., \& LewisFernández, R. (2016). The role of cultural psychiatry in improving the policy response to Central America's unaccompanied minors at the American border: Local and global implications. International Journal of Cultural Mental Health 9(4), 381386. doi: https://doi.org/10.1080/17542863.2016.1225110

American Federation of Teachers. (n.d.). National \& local refugee relief efforts for unaccompanied children. Retrieved from https://www.aft.org/national-local-refugeerelief-efforts-unaccompanied-children

Alter, C. (2009). Building community partnerships and networks. In R. Patti (Ed.), The handbook of human services management (2nd ed., pp. 435-454). Thousand Oaks, CA: Sage Publications.

Applied Research Center. (2011). Shattered families: The perilous intersection of immigration enforcement and the child welfare system. Retrieved from https://www.raceforward.org/research/reports/shattered-families

Barillas-Chón, D. (2010). Oaxaqueño/a students' (un)welcoming high school experiences. Journal of Latinos and Education, 9(4), 303-320. doi: https://doi.org/10.1080/15348431.2010.491043

Beninghof, A., \& Leensvaart, M. (2016). Co-teaching to support ELLs. Educational Leadership, 73(5), 70-73.

Blood Weekly. (2016). Studies from medical university yield new data on organ transplants. Blood Weekly, 30.

Booi, Z., Callahan, C., Fugere, G., Harris, M., Hughes, A., Kramarczuk, A., Kurtz, C., Reyes, R....Swaminatha, S. (2016). Ensuring every undocumented student succeeds: A report on access to public education for undocumented children. Retrieved from Georgetown Law Human Rights Institute website https://www.law.georgetown.edu/human-rights-institute/our-work/fact-findingproject/ensuring-every-undocumented-student-succeeds-a-report/. Bridging Refugee Youth and Children's Services. (2016). Schools. Retrieved from http://www.brycs.org/schools.cfm

Calvo, R., Teasley, M. Goldbach, J., McRoy, R., \& Padilla, Y. (2018). Achieve equal opportunity and justice. In R. Fong, J. E. Lubben, \& R. P. Barth (Eds.), Grand Challenges for Social Work and Society (pp. 248-264). NY, New York: Oxford University Press.

Cardoso, J. B., Brabeck, K., Stinchcomb, D., Heidbrink, L., Price, O. A., Gilgarci A, O., Crea, T. M., \& Zayas, L. H. (in press). Challenges to integration for unaccompanied 
migrant youth in the post-release U.S. context: A call for research. Journal of Ethnic and Migration Studies.

Carlson, B., Cacciatore, J., \& Klimek, B. (2012). Risk and resilience perspective on unaccompanied refugee minors. Social Work, 57(3), 259-269. doi: https://doi.org/10.1093/sw/sws003.

Catholic Legal Immigration Network. (2016). Interior enforcement executive order and DHS memo. Retrieved from https://cliniclegal.org/resources/interior-enforcementexecutive-order-and-dhs-memo-faqs

CME Learning. (2017). New 2016 ACA rules significantly affect the law of language access. Retrieved from https://www.cmelearning.com/new-2016-aca-rulessignificantly-affect-the-law-of-language-access/

Court Interpreters Act. (1978). Public Law 95-539, 28 U.S.C. §1827

Crea, T. M., Hasson, R. G., Evans, K., Berger Cardoso, J., \& Underwood, D. (2017a). Moving forward: Educational outcomes for existing unaccompanied refugee minors (URM) foster care in the United States. Journal of Refugee Studies. doi: https://doi.org/10.1093/jrs/fex020.

Crea, T. M., Lopez, A., Taylor, T., \& Underwood, D. (2017b). Unaccompanied migrant children in the United States: Predictors of placement stability in long term foster care. Children and Youth Services Review, 73, 93-99. doi: https://doi.org/10.1016/j.childyouth.2016.12.009.

Cultural Orientation Resource Center. (2018). About cultural and community orientation. Retrieved from http://www.culturalorientation.net/providing-orientation/about

Customs and Border Protection [CBP]. (2016). United States Border Patrol Southwest family unit subject and unaccompanied alien children apprehensions Fiscal Year 2016. Retrieved from https://www.cbp.gov/newsroom/stats/southwest-borderunaccompanied-children/fy-2016.

CBP. (2017). U.S. Border Patrol Southwest border apprehensions by sector FY2017. Retrieved from https://www.cbp.gov/newsroom/stats/usbp-sw-border-apprehensionsfy2017\#

CBP. (2018). Southwest border migration FY2018. Retrieved from https://www.cbp.gov/newsroom/stats/sw-border-migration.

De Genova, N., \& N. Peutz (Eds.). (2010). The deportation regime: Sovereignty, space, and the freedom of movement. Durham: Duke University Press. doi: https://doi.org/10.1215/9780822391340.

Department of Health and Human Services [HHS]. (2018). Putting America's health first: FY2019 President's Budget for HHS. Retrieved from https://www.hhs.gov/sites/default/files/fy-2019-budget-in-brief.pdf

Dettlaff, A. J., \& Cardoso, J. B. (2010). Mental health needs and service use among Latino children of immigrants in the child welfare system. Children and Youth 
Services Review, 32, 1373-1379. doi:

https://doi.org/10.1016/j.childyouth.2010.06.005

DiNitto, D. M. (2011). Social welfare: Politics and public policy (7th ed.). Boston, MA: Allyn \& Bacon.

Earner, I. (2005). Immigrant children and youth in the child welfare system: Immigration status and special needs in permanency planning. In G. Mallon \& P. Hess (Eds.), Child welfare for the 21st century (pp. 655- 665). New York, NY: Columbia University Press.

Equal Educational Opportunities Act of 1974 [EEOA]. (1974). Public Law 93-380. 20 USC Sec. 1701-1758

Evenhuis, M. (2013). Child-proofing asylum: Separated children and refugee decision making in Australia. International Journal of Refugee Law, 25(3), 535-573. doi: https://doi.org/10.1093/ijrl/eet037.

Evans, K., Perez-Aponte, J., \& McRoy, R. (in press). Without a paddle: Barriers to school enrollment procedures for immigrant students and families. Education and Urban Society.

Flores v. Reno, Case No. CV 85-4544-RJK (C.D. CA, 1997)

Grabenstein, J. (2013). What the world's religions teach, applied to vaccines and immune globulins. Vaccine, 31(16), 2011-2023. doi: https://doi.org/10.1016/j.vaccine.2013.02.026

Griffin, M., Son, M., \& Shapleigh, E. (2014). Children's lives on the border. Pediatrics, 133(5), e1118-e1120. doi: https://doi.org/10.1542/peds.2013-2813.

Hacker, K., Anies, M., Folb, B., \& Zallman, L. (2015). Barriers to healthcare for undocumented immigrants: A literature review. Risk Management and Healthcare Policy, 2015(8), 175-183. doi: https://doi.org/10.2147/RMHP.S70173.

Haider, S. J., Schoeni, R. F., Bao, Y., \& Danielson, C. (2004). Immigrants, welfare reform, and economy. Journal of Policy Analysis \& Management, 23(4), 745-764. doi: https://doi.org/10.1002/pam.20045

Halpern, P. (2008). Refugee economic self-sufficiency: An exploratory study of approaches used in Office of Refugee Resettlement programs. Report retrieved from the U.S. Department of Health and Human Services Office of the Assistant Secretary for Planning and Evaluation https://aspe.hhs.gov/system/files/pdf/75561/report.pdf

Homeland Security Act of 2002. (2002). Public Law 107-296, 6 U.S.C. § 279

International Committee of the Red Cross [ICRC]. (n.d.). Restoring family links. Retrieved from https://familylinks.icrc.org/en/Pages/home.aspx

International Human Rights Clinic. (2015). Registering rights: Syrian refugees and the documentation of births, marriages, and deaths in Jordan. Retrieved from 
http://hrp.law.harvard.edu/wp-content/uploads/2015/11/Registering-rights-reportNRC-IHRC-October20151.pdf

International Social Service-USA Branch. (2017). Services for children. Retrieved from http://www.iss-usa.org/services/services-for-children

Kennedy, E. G. (2013). Unnecessary suffering: Potential unmet mental health needs of unaccompanied alien children. JAMA Pediatrics, 167(4), 319-320. doi: https://doi.org/10.1001/jamapediatrics.2013.1382.

Kids in Need of Defense [KIND]. (2016). Improving protection and fair treatment of unaccompanied children. Retrieved from https://supportkind.org/wpcontent/uploads/2016/09/KIND-Protection-and-Fair-Treatment-Report_September2016-FINAL.pdf

Kohli, R. K. S. (2011) Working to ensure safety, belonging and success for unaccompanied asylum-seeking children. Child Abuse Review, 20(5), 311-323. doi: https://doi.org/10.1002/car.1182

Kumi-Yeboah, A., \& Smith, P. (2017). Cross-cultural educational experiences and academic achievement of Ghanaian immigrant youth in urban public schools. Education and Urban Society, 49(2), 434-455. doi: https://doi.org/10.1177/0013124516643764

Linsk, N. (2014). Strengthening families through para professionals in the social service workforce. Presentation for Global Social Service Workforce Alliance Symposium. Retrieved from http://www.socialserviceworkforce.org/system/files/resource/files/Strengthening\%20 Families\%20through\%20Para\%20Professionals\%20in\%20the\%20SSW\%20\%20Alliance\%20April\%202014\%20Symposium.pdf

López, G., \& Radford, J. (2017). Facts on U.S. Immigrants, 2015: Statistical portrait of the foreign-born population in the United States. Retrieved from the PEW Research Center website: http://www.pewhispanic.org/2017/05/03/facts-on-u-s-immigrantscurrent-data/

Migration Policy Institute [MPI]. (2015). Unaccompanied child migrants in U.S. communities, immigration court, and schools. Retrieved from http://www.migrationpolicy.org/research/unaccompanied-child-migrants-uscommunities-immigration-court-and-schools

Morland, L., Duncan, J., Hoebing, J., Kirschke, J., \& Schmidt, L. (2005). Bridging refugee youth and children's services: A case study of cross-service training. Child Welfare, 84(5), 791-812.

National Association of Social Workers [NASW]. (1996). Code of ethics. Retrieved from https://www.socialworkers.org/About/Ethics/Code-of-Ethics/Code-of-Ethics-English

Oxman-Martinez, J., \& Choi, Y. R. (2014). Newcomer children: experiences of inclusion and exclusion, and their outcomes. Social Inclusion, 2(4), 23-37. doi: https://doi.org/10.17645/si.v2i4.133 
Pardini, P. (2006). In one voice: Mainstream and ELL teachers work side-by-side in the classroom, teaching language through content. The Journal of Staff Development, 27(4), 20-25.

Paat, Y. (2013). Working with immigrant children and their families: An application of Bronfenbrenner's Ecological Systems Theory. Journal of Human Behavior in the Social Environment 23, 954-966. doi: https://doi.org/10.1080/10911359.2013.800007.

Patil, C. L., Mcgown, M., Nahayo, P. D., \& Hadley, C. (2010). Forced migration: complexities in food and health for refugees resettled in the United States. NAPA Bulletin, 34(1), 141-160. doi: https://doi.org/10.1111/j.1556-4797.2010.01056.X.

Perreira, K. M., \& Ornelas, I. J. (2011). The physical and psychological well-being of immigrant children. Future of Children, 21(1), 195-218. doi: https://doi.org/10.1353/foc.2011.0002.

Personal Responsibility and Work Opportunity Reconciliation Act (PRWORA) of 1996. (1996). Public Law 104-193

Pine, B. A., \& Drachman, D. (2005). Effective child welfare practice with immigrant and refugee children and their families. Child Welfare, 84(5), 537-562.

Piwowarczyk, L. A. (2006). Our responsibility to unaccompanied and separated children in the United States: A helping hand. Boston University Public Interest Law Journal, 15(2), 263-296.

Pottie, K., Greenaway, C., Feightner, J., Welch, V., Swinkels, H., Rashid, M...Tugwell, P. (2011). Evidence-based clinical guidelines for immigrants and refugees. CMAJ: Canadian Medical Association Journal,183(12), E824-925. doi: https://doi.org/10.1503/cmaj.090313

Raghallaigh, M. (2011). Religion in the lives of unaccompanied minors: An available and compelling coping resource. The British Journal of Social Work, 41(3), 539-556. doi: https://doi.org/10.1093/bjsw/bcq136

Ramirez, W., McKenna, M., \& Somers, A. (2015). Repatriation and reintegration of migrant children. In K. Musalo, L. Frydman, \& P. C. Cernados (Eds.), Childhood and migration in Central and North America: Causes, policies, practices and challenges (pp. 455-480). San Francisco, CA: Center for Gender and Refugee Studies.

Redden, M. (2017). Undocumented immigrants avoid vital nutrition services for fear of deportation. Retrieved from https://www.theguardian.com/usnews/2017/may/09/undocumented-immigrants-wic-nutrition-services-deportation

Roth, B. J., \& Grace, B. L. (2015). Falling through the cracks: The paradox of postrelease services for unaccompanied child migrants. Children and Youth Services Review, 58, 244-252. doi: https://doi.org/10.1016/j.childyouth.2015.10.007.

Shore, B., Hammond, D., \& Celep A. (2013). When good is not good enough. Stanford Social Innovation Review, Fall 2013, 40-47. 
Socha, K. (2014). Challenges and solutions to family reunification efforts with undocumented or foreign-born youth. Focus, 20(3), 16-18.

Socha, K., Mullooly, A. and Jackson, J. (2016). Experiences resettling Eritrean youth through the US unaccompanied refugee minor program. Journal of Human Rights and Social Work 1(2), 96-106.

Trickett, E., Jones, C., \& Nagayama Hall, G. G. (2007). Adolescent culture brokering and family functioning: A study of families from Vietnam. Cultural Diversity and Ethnic Minority Psychology, 13(2), 143-150. doi: https://doi.org/10.1037/10999809.13.2.143.

United Nations High Commissioner for Refugees [UNHCR]. (2014). Children on the run: Unaccompanied children leaving Central America and Mexico and the need for international protection. Retrieved from http://www.unhcr.org/en-us/aboutus/\%20background/56fc266f4/\%20children-on-the-run-full-report.html.

UNHCR. (2016). Global trends. Retrieved from http://www.unhcr.org/en-us/globaltrends-2016-media.html?query=Global\%20trends.

United States Conference of Catholic Bishops [USCCB]. (2012). Improving access: Immigration relief for children in federal foster care before and after the Trafficking Victims Protection Reauthorization Act of 2008. Retrieved from http://www.usccb.org/about/children-and-migration/unaccompanied-refugee-minorprogram/upload/Immigration-Relief-for-Children-in-Federal-Foster-Care-Beforeand-After-TVPRA-2008 USCCB-December-2012.pdf

USCCB. (2013a). Mission to Central America: The flight of unaccompanied children to the United States. Retrieved from http://www.usccb.org/about/migrationpolicy/upload/Mission-To-Central-America-FINAL-2.pdf

USCCB. (2013b). The United States unaccompanied refugee minor program: Guiding principles and promising practices. Retrieved from http://www.usccb.org/about/children-and-migration/unaccompanied-refugee-minorprogram/upload/united-states-unaccompanied-refugee-minor-program-guidingprinciples-and-promising-practices.pdf

USCCB \& Lutheran Immigration and Refugee Service (n.d.). Post-Release Services: Family preservation services for immigrant children released from federal custody. Retrieved from http://www.usccb.org/about/children-and-migration/upload/LIRSand-USCCB-Post-Release-Services-FAQs-Final.pdf.

U.S. Department of Education [US DOE]. (2004). Laws \& guidance: Part c- Homeless education. Retrieved from http://www2.ed.gov/policy/elsec/leg/esea02/pg116.html.

US DOE. (2014). Educational services for immigrant children and those recently arrived to the United States. Retrieved from http://www2.ed.gov/policy/rights/guid/unaccompanied-children.html

US DOE. (2016). Non-regulatory guidance: English Learners and Title III of the Elementary and Secondary Education Act (ESEA), as amended by the Every Student 
Succeeds Act (ESSA). Retrieved from

https://www2.ed.gov/policy/elsec/leg/essa/essatitleiiiguidenglishlearners92016.pdf.

U.S. Department of State. (2017). Intercountry adoption: Who can be adopted. Retrieved from https://travel.state.gov/content/adoptionsabroad/en/adoption-process/how-toadopt/who-can-be-adopted.html

Waters, M. C., \& Pineau, M. G. (Eds.). (2015). The integration of immigrants into American society. Washington, DC: The National Academies Press. doi: https://doi.org/10.17226/21746

William Wilberforce Trafficking Victims Protection Reauthorization Act (TVPRA) of 2008. (2008). Public Law 110-457, 8 U.S.C. § 1232

Young Center for Immigrant Children's Rights. (n.d.). Child advocate program. Retrieved from https://www.theyoungcenter.org/child-advocate-program-youngcenter/.

Author note: Address correspondence to: Kerri Evans, MSW, LCSW. Boston College School of Social Work, McGuinn Hall Room 204. 140 Commonwealth Avenue, Chestnut Hill, MA 02467 kerri.evans@bc.edu 